\title{
Concentration of Serotonin And 5 Hydroxy Indole Acetic Acid in Discrete Brain Regions of Overiectomized And Estradiol Treated Female Rats
}

\author{
D.Jaba Jaya Rani ${ }^{1}$, Dr.Suthanthira Rajan,Ph.D ${ }^{2}$. Rtd Prof. Physiology \\ ${ }^{I}$ Tutor In Physiology, Kanyakumari Govt. Medical College,Asaripallam, Nagercoil, India. \\ ${ }^{2}$ Dr.ALM Post Graduate, Institute Of Basic Medical Sciences University Of Madras, India.
}

\begin{abstract}
Back Ground: Estrogen is the sex hormone that causes the development and maintenance female secondary sexual characters. Post menopausal women increasing in vulnerable to depression due to the reduced estrogen production. The activity of estrogen on serotonin has anti depressant characteristics. A higher level serotonin activity is associated with Positive mood while decreased activity is associated with depressive mood. Estrogen boosts the activity of serotonin.
\end{abstract}

Objectives: To determine the brain serotonin and its major metabolite 5HIAA in ovariectomized rats at different day intervals and after estradiol treatment.

Methodology: Female albino rats of wister strain where ovariectomized and treated with ethanyl estradiol, Brain serotonin and 5HIAA was estimated by Fluoremetric method. Data was analysed by student's $t$ test. Result: Reduction in serotonin and 5HIAA level in Hypothalamus, striatum and pons medulla after ovariectomy and increased in estradiol treated rats.

Conclusion: Estrogen may be used as effective anti depressant after further studies.

\section{Introduction}

Estrogen is the sex hormone, that causes the development and maintenance of female secondary sexual characters. Post menopausal women increasingly vulnerable to depression due to the reduced estrogen production. The activity of estrogen on neurotransmitter has anti depressant characteristic ${ }^{1}$.(Weissman, 1996). . A higher level of serotonin activity is associated with positive mood while decreased activity is associated with depressive mood. Estrogen boost the activity of serotonin.Estrogen deficiency leads to vasomotor instability (hot flushes and night sweat) while deprivation leads to urogenital atropy, osteoporosis and tooth loss, atherosclerosis and coronary heart disease and potentially increase the risk of dementias ${ }^{2}$.During menopause women experience hormonal and chemical changes. There is a decrease in the level of estrodiol, the principal estrogen of women ${ }^{4}$. Prolonged estrogen deficiency may be associated with impairment in estradiol receptor in the brain. Estradiol receptor may be important in the facilitatory effect that estrogen has on the activity of serotonin and, when the receptors are impaired the estrogen does not work as well and is unable to facilitate the serotonin ${ }^{5}$.

\section{Aim Of The Present Study}

1. To find out the concentration of serotonin and its major metabolite 5HIAA in different brain regions of rat at different day intervals after ovariectomy.

2. To find the concentration of serotonin and its major metabolite 5HIAA in different brain regions at 24 hours and 36 hours after estradiol treatment to ovariectomized rat.

\section{Materials And Methods}

Healthy matured female albino rats of wister strain $(180-220 \mathrm{~g})$ were used in the present investigation. The animals were maintained in a well ventilated and fed with standard balanced rat pellet diet ( Gold Mohur Hindis tain liver Ltd. Bombay India ) and drinking water was made available ad libitum.

Experimental animals were divided into 6 groups all are female.

Group I Control rats. This group consist of 6 Normal rats.

Group II Ovariectomized rats. Sacrificed after 5 days $(n=6)$.

Group III Ovariectomized rats. Sacrificed after 10 days $(n=6)$.

Group IV Ovariectomized rats. Sacrificed after 15 days $(n=6)$.

Group V Ovariectomized rats treated with $20 \mu \mathrm{g}$ Ethinyl Estradiol sacrificed after 24 hours $(\mathrm{n}=6)$.

Group VI Ovariectomized rats treated with $20 \mu \mathrm{g}$ Ethinyl Estradiol sacrificed after 36 hours $(\mathrm{n}=6)$. 
Concentration Of Serotonin And 5 Hydroxy Indole Acetic Acid In Discrete Brain Regions of...

\subsection{Dissection And Regionation Of Rat Brain}

Rats were sacrificed by rapid decapitation, without initial disturbance for substantial changes in brain amines may occur within few minutes, if the animals were disturbed unduly before sacrifice ${ }^{8}$ (Welch and Welch 1968 ) Anaesthesia was not used because it also alters the brain amines ${ }^{7}$ Vogt 1954, Schanberg et al 1967.The skin from the top of the head was removed with a couple of incisions and cut off the occipital muscles from the occipital bone, revealing the foramen magnum. One blade of the scissors was cautiously introduced into the foraman. The blade was kept parallel to the inner wall of the calvarium and close to it as possible to avoid damaging the brain cuts were made through the bone. The cuts extended rostrally as far as the bregma suture. After two parallel cuts through the bone were made, the bone was lifted forward and its point of attachment rostrally was broken. The head was held more upward and closed scissors were slipped under the frontal lobe and the brain was gently separated from the skull. Optic nerve which leaves the brain base was severed. Finally the brain was taken out of the skull after trigeminal nerves were cut.The brain removed was transferred to an ice cold glass plate. The brain regions were dissected following the procedure of ${ }^{9}$ Golowinski and lversion(1966). The following regions were separated : cerebellum, Pons-medulla, Hypothalamus,Striatum, Midbrain, and cerebral cortex.All regions were blotted immediately and weighted separately in a electrical monopan balance.

\subsection{Fluoremetric Estimation Of Tissue Serotonin And 5 hiaa ${ }^{10}$ By The Method Of Curzon And Green} (1970).

All the chemicals used were of Analytical reagent grade and all glass double distilled water was used throughout for preparing various solutions.The excised brains were dissected out into 6 major parts and weighed. The cortex was homogenized in 10 volumes of cold acidified $n$ butanol and all other areas (weighing less than $300 \mathrm{mg}$ ) were homogenized in $3 \mathrm{ml}$ of acidified butanol. The homogenate were centrifuged at 3000 rpm fo5 5 minutes. The clear supernatant was divided in to two equal aliquots.

1.To one of the sample in a $15 \mathrm{ml}$ centrifuge tube was added $5 \mathrm{ml}$ of heptan and $0.4 \mathrm{ml}$ of $0.1 \mathrm{~N} \mathrm{Hcl}$ containing $0.1 \%$ L cystine.

2. The second aliquot was processed similar to the above, step instead of $0.1 \mathrm{~N} \mathrm{Hcl}$ containing $0.1 \%$ Cystine, $0.4 \mathrm{ml}$ of known amount of $5 \mathrm{HT}$ internal standard was added.

3. Reagent blank contained $2.5 \mathrm{ml}$ of acid butanol $5 \mathrm{ml}$ of heptan and $0.4 \mathrm{ml}$ of $0.1 \% \mathrm{~N} \mathrm{Hcl}$ containing $0.1 \% \mathrm{~L}$ cysteine was added.

The all tubes were then shaken for 5 minutes and centrifuged at 3000rpm for 5 minutes.

$5 \mathrm{ml}$ of the organic phase retained for 5HIAA determination.

To determine $5 \mathrm{HT}, 0.1 \mathrm{ml}$ samples of the aqueous phase were pipette out into test tubes and added $0.6 \mathrm{ml}$ of $0.004 \%$ OPT in $10 \mathrm{~N} \mathrm{Hcl}$. After mixing the tubes were kept in boiling water bath for 15 minutes. The tubes were cooled in water and flurocence unit were measured for $5 \mathrm{HT}$ is $360 / 470 \mathrm{~nm}$. To determine 5HIAA $5 \mathrm{ml}$ of organic phase was pipette out into $15 \mathrm{ml}$ centrifugal tube. To the sample tube $6 \mathrm{ML}$ of $0.5 \mathrm{M}$ phosphate buffer was added. In the reagent blank tube, also $6 \mathrm{ML}$ of $0.5 \mathrm{M}$ phosphate buffer was added. In the standard tube $0.6 \mathrm{ml}$ of 5HIAA internal standard was added and processed similar. The above all tubes were shaken for 10 minutes and centrifugal at 300rpm for 3 minutes. $0.2 \mathrm{ml}$ of aqueous phase was extracted and pipette out into test tubes and added $0.02 \mathrm{ml}$ of $1 \%$ cysteine solution, $0.4 \mathrm{ml}$ of conc $\mathrm{Hcl}, 0.02 \mathrm{ml}$ of $0.1 \%$ OPT and $0.02 \mathrm{ml}$ of $0.02 \%$ periodate solutions were added. The tubes were placed in boiling water for 10 minutes and cooled in water and read at activation $360 \mathrm{~nm}$ flurence $470 \mathrm{~nm}$. The concentration of $5 \mathrm{HT}$ and HIAA present in the samples were calculated according to the procedure of Ansell and Beeson $(1968)^{30}$.
A-blank $x \quad$ Conc of Std
$\mathrm{x} \quad \mathrm{x}$
2.5
$=\mu \mathrm{g} / \mathrm{gm}$ of tissue
B-A
$\mathrm{y}$

\section{Where}

$\begin{array}{lll}\mathbf{A} & = & \text { florescence unit obtained from tissue alone } \\ \mathbf{B} & = & \text { florescence obtained from tissue }+ \text { mixed std } \\ \mathbf{X} & = & \text { Volume of Butanol } \\ \mathbf{Y} & = & \text { Weight of tissue in grames } \\ \mathbf{2 . 5} & = & \text { Volume of homogenate used }\end{array}$

\section{Statistical Analysis}

The values are expressed as mean, S.D.statistically significant variations between the groups arrived at using students ' $t$ test' 
Concentration Of Serotonin And 5 Hydroxy Indole Acetic Acid In Discrete Brain Regions of...

\section{Results}

Table - 1 Effect Of Ovariectomy On 5ht ( $\mu \mathrm{g} / \mathrm{Gm}$ Of Tissue) Levels In Different Brain Regions Of Female Rats

\begin{tabular}{|l|l|l|l|l|}
\hline Brain Regions & $\begin{array}{l}\text { Control } \\
\text { (Normal Rats) }\end{array}$ & $5^{\text {th }}$ day after Ovariectomy & $\begin{array}{l}10^{\text {th }} \text { day after } \\
\text { Ovariectomy }\end{array}$ & $\begin{array}{l}15^{\text {th }} \text { day after } \\
\text { Ovariectomy }\end{array}$ \\
\hline Hypothalamus & $1.342 \pm 0.236$ & $1.022 \pm 0.20$ & $0.946 \pm 0.098$ & $0.8076 \pm 0.0219$ \\
\hline Striatum & $1.086 \pm 0.119$ & $1.019 \pm 0.138$ & $0.895 \pm 0.226$ & $0.6494 \pm 0.0109$ \\
\hline Mid Brain & $0.340 \pm 0.126$ & $0.245 \pm 0.059$ & $0.288 \pm 0.046$ & $0.094 \pm 0.009$ \\
\hline Pons Medulla & $1.461 \pm 0.016$ & $0.018 \pm 0.098$ & $0.865 \pm 0.050^{*}$ & $0.865 \pm 0.007^{* *}$ \\
\hline Cerebral- Cortex & $0.161 \pm 0.016$ & $0.244 \pm 0.050^{*}$ & $0.0203 \pm 0.099^{* *}$ & $0.03937 \pm 0.002$ \\
\hline Cerebellum & $0.132 \pm 0.051$ & $0.019 \pm 0.038^{*}$ & $0.083 \pm 0.011$ & $0.0933 \pm 0.0070$ \\
\hline
\end{tabular}

$* \mathrm{P}<.05$

$* * \mathrm{P}<.01$

$* * * \mathrm{P}<.001$

*When control rats were compares with ovariectomized rats.

Table - 2: Effect Of Estradiol Treatment To Ovariectomized Rat In $5 \mathrm{ht}$ Level $(\mu \mathrm{g} / \mathrm{Gm}$ Of Tissue)

\begin{tabular}{|l|l|l|l|l|}
\hline Brain Regions & $\begin{array}{l}\text { Control } \\
\text { (Normal Rats) }\end{array}$ & $\begin{array}{l}10^{\text {th }} \text { day after } \\
\text { Ovariectomy }\end{array}$ & $\begin{array}{l}\text { Estradiol Treated } \\
24 \quad \text { hrs } \\
\text { after(ovariectomized) }\end{array}$ & $\begin{array}{l}\text { Estradiol Treated 36 hrs } \\
\text { after ovariectomized) }\end{array}$ \\
\hline Hypothalamus & $1.342 \pm 0.236$ & $0.946 \pm 0.098$ & $0.844 \pm 0.08^{* * \dagger}$ & $0.989 \pm 0.343$ \\
\hline Striatum & $1.086 \pm 0.119$ & $0.895 \pm 0.226$ & $0.941 \pm 0.091 *$ & $0.890 \pm 0.083$ \\
\hline \multicolumn{1}{c|}{ Mid Brain } & $0.340 \pm 0.126$ & $0.288 \pm 0.046$ & $0.351 \pm 0.04$ & $0.331 \pm 0.059$ \\
\hline Pons Medulla & $1.461 \pm 0.016$ & $0.865 \pm 0.050$ & $0.717 \pm 0.059$ & $0.961 \pm 0.340$ \\
\hline Cerebral- Cortex & $0.161 \pm 0.016$ & $0.0203 \pm 0.099$ & $0.11 \pm 0.172$ & $0.141 \pm 0.017$ \\
\hline Cerebellum & $0.132 \pm 0.051$ & $0.083 \pm 0.011$ & $0.092 \pm 0.38$ & $0.981 \pm 0.030$ \\
\hline
\end{tabular}

$* \mathrm{P}<.05$

$* * \mathrm{P}<.01$

$* * * \mathrm{P}<.001$

* When 10 day ovariectomized rats compared with $36 \mathrm{hrs}$ estradiol treated rats $\dagger$ When control rats compared with Aa $24 \mathrm{hrs}$ estradiol treated rats.

Table - 3: Effect Of Ovariectomy On 5hiaa ( $\mu \mathrm{g} / \mathrm{Gm}$ Of Tissue) Levels In Different Brain Regions Of Female Rats

\begin{tabular}{|l|l|l|l|l|}
\hline Brain Regions & $\begin{array}{l}\text { Control } \\
\text { (Normal Rats) }\end{array}$ & $5^{\text {th }}$ day after Ovariectomy & $\begin{array}{l}10^{\text {th }} \\
\text { Ovariectomy after }\end{array}$ & $\begin{array}{l}15^{\text {th }} \text { day after } \\
\text { Ovariectomy }\end{array}$ \\
\hline Hypothalamus & $0.8417 \pm 0.18$ & $0.6109 \pm 0.082$ & $0.5076 \pm 0.0219^{*}$ & $0.5071 \pm 0.0225^{* *}$ \\
\hline Striatum & $0.6592 \pm 0.19$ & $0.7966 \pm 0.035^{*}$ & $0.6494 \pm 0.010$ & $0.6816 \pm 0.07$ \\
\hline Mid Brain & $0.1343 \pm 0.14$ & $0.01162 \pm 0.0253^{*}$ & $0.094 \pm 0.0070$ & $0.111 \pm 0.0169$ \\
\hline Pons Medulla & $1.1739 \pm 0.04$ & $0.6539 \pm 0.056$ & $0.588 \pm 0.007 *$ & $0.597 \pm 0.0014$ \\
\hline Cerebral- Cortex & $0.1139 \pm 0.022$ & $0.1435 \pm 0.0070$ & $0.03937 \pm 0.002$ & $0.02 \pm 0.0141^{*}$ \\
\hline Cerebellum & $0.1348 \pm 0.026$ & $0.1398 \pm 0.0070$ & $0.0933 \pm 0.008$ & $0.0696 \pm 0.0184^{*}$ \\
\hline
\end{tabular}

$* \mathrm{P}<.05$

$* * \mathrm{P}<.01$

$* * * \mathrm{P}<.001$

*When control rats were compared with ovariectomized rats. 
Concentration Of Serotonin And 5 Hydroxy Indole Acetic Acid In Discrete Brain Regions of...

Table - 4: Effect Of Estradiol Treatment In 5hiaa Level In Ovariectomized RAT ( $\mu \mathrm{g} / \mathrm{gm}$ of tissue)

\begin{tabular}{|l|l|l|l|l|}
\hline Brain Regions & $\begin{array}{l}\text { Control } \\
\text { (Normal Rats) }\end{array}$ & $\begin{array}{l}10^{\text {th }} \text { day after } \\
\text { Ovariectomy }\end{array}$ & $\begin{array}{l}\text { Estradiol Treated } \\
24 \quad \text { hrs } \\
\text { after(ovariectomized) }\end{array}$ & $\begin{array}{l}\text { Estradiol Treated 36 hrs } \\
\text { after ovariectomized) }\end{array}$ \\
\hline Hypothalamus & $0.8417 \pm 0.18$ & $0.946 \pm 0.098$ & $0.522 \pm 0.001 \dagger$ & $0.644 \pm 0.002$ \\
\hline Striatum & $0.6592 \pm 0.19$ & $0.895 \pm 0.226$ & $0.672 \pm 0.0834$ & $0.862 \pm 0.036$ \\
\hline Mid Brain & $0.1343 \pm 0.14$ & $0.288 \pm 0.046$ & $0.1112 \pm 0.0172$ & $0.212 \pm 0.004$ \\
\hline Pons Medulla & $1.01739 \pm 0.04$ & $0.588 \pm 0.050$ & $0.328 \pm 0.0063$ & $0.428 \pm 0.032$ \\
\hline Cerebral- Cortex & $0.1139 \pm 0.022$ & $0.0203 \pm 0.099$ & $0.1540 \pm 0.079 * *$ & $0.112 \pm 0.012$ \\
\hline Cerebellum & $0.1348 \pm 0.026$ & $0.083 \pm 0.011$ & $0.06697 \pm 0.018^{*}$ & $0.09 \pm 0.034$ \\
\hline
\end{tabular}

$* \mathrm{P}<.05$

$* * \mathrm{P}<.01$

$* * * \mathrm{P}<.001$

* When 10 day ovariectomized rats compared with24hrs estradiol treated rats $\dagger$ When control rats compared with $36 \mathrm{hrs}$ estradiol treated rats.

\section{Discussion}

Estradiol administration increases the production of neurotransmitters like serotonin. It also increases the number of serotonin receptors in hypothalamus ${ }^{16}$ (Coope, J ( 1996 ) Estradiol exerts significant positive effects on the viability and survival of cortical neurons. Cultured neurons exposed components of CEE and equilin and 17 Beta estradiol have shown a similar effect by enhancing neuronal survival, estradiol preserves the information processing capability and storage capacity for brain cell.The effect of estradiol was to reduce the activity of monoamine oxidase, there is not a likely explanation for the increase in serotonin content since concentration of 5HIAA was increased proportionately as evidenced by the constant ration of 5HIAA concentration to that of serotonin. A more plausible explanation would be a stimulation of tryptophan hyroxydase by estradiol the effects of other hormones on this enzymes activity are not conclusive ${ }^{13}$ (Kizer et al 1973 ) changes in serotonin contents are seen in the dorsal raphe nucleus, the major site of serotonergic cell bodies and also with substantia nigra a region known to contain mainly terminals ${ }^{11}$ (parent et al 1981) which drives in major past from the dorsal raphe nucleus ${ }^{14}$ ( Fibiger and Miller 1977 ).Other regions of fore brain and hind brain, known to receive innervations from the dorsal raphe nucleus were not affected by estradiol treatment with injection of $5 \mu \mathrm{g} / \mathrm{rat}$ to ovariectomized rat ( Crowely at al 1979) observed. No changes in several nuclei of forebrain rostral and medical hypothalamus and midbrain tegmentum. However they did not assay the dorsal raphe nucleus the major size of serotonin cell nor did they investigate the substantia nigra with a similar estrogen administration schedule as Crowley et al (1979) ${ }^{12}$ namely one estradiol benzoate $20 \mu \mathrm{g} / \mathrm{kg}$ to overiectomized rats 53 hrs before killing ${ }^{17}$ (cone et al 1981) has also observed no changes in serotonin levels in several brain areas expect the raphe. With an acute injection of $17 \AA$ estradiol at a different dose and time interval between injection of $17 ß$ estradiol at a different dose and time an increase in serotonin levels in the raphe while the other region are unaffected. Cone et al (1981) reported that there was increased in 5HT level after the administration of estrogen along with progesterone to overaiectomized rats in some regions. So therefore estrogen can be effectively administered as an anti depressive agent after further studies.

\section{Conclusion}

In this study the levels of serotonin (5HT) and its major metabolic 5HIAA was measured .It was observed that the level of 5HT was decreased in hypothalamus, striatum,mid brain and cerebral cortex but not equally in 5 days, 10days and 15days after ovariectomized rats. 5HIAA levels in hypothalamus and cerebral cortex was decreased significantly after 15 days of ovariectomy.In estradiol treated ovariectomized rats. 5HT and 5HIAA level was increased in hypothalamus striatum and ponsmedulla.

\section{Bibliography}

[1]. Weissman, M.M., ( 1996 ) Epiderminology of major , depression in women , presented at the American psychiatric association annual meeting May 4, 1996 New York. Mc Ewen, B.S. ( 1999 )

[2]. The modular and neuroanatamical basis for estrogen effects in the central nervous system J Clin Endocrinol Metab, 84(6): 17901797

[3]. Stefens, D.C., Norton , M.C., Plassman, B.L., Tschanzs, J.A., Wyse, B.W.,Welsh (1999 ) Enhanced Conginitive performance with estrogen us in non demented community dwelling order women.

[4]. J.Am Gerials Soc.47 : 1171 -1175. Halbreich,U., Chakravarthy.S.G.(1997)

[5]. The influence of estrogen on monoamine oxidize activity. Psychopharmacholy Bull, 33: 227-33

[6]. Hal breaich, U. ( 1997 ) Role of estrogen in postmenopausal depression. Neurology 48 : 516 -520.

DOI: 10.9790/0853-1508014852 $\quad$ www.iosrjournals.org $51 \mid$ Page


[7]. Zarrow,M.X.,Vochem,J.M and Mc Carthy, J.L.(1984).

[8]. In Experimental Endocrinology.A source Book of Basic Techniques . Academic press, Newyork,pp 39-44 Vogt,M.(1954 )

[9]. The concentration of sympathin in different parts of the CNS under normal condition after administration of drugs. J.Physiol 123 : $451-81$

[10]. Welch,A.S.and Welch, B.L.,( 1968 ) Effects of stress and parachlorophenyl action upon brain catecholamine in grouped and isolated mice.Biochem pharmacol , $17: 699-708$

[11]. Glowinsk,J.and Iverson,L.L ( 1966 ) Regional studies of catecholamine's in the rat brain. The disposition of (H) dopamine a (3H) DOPA in various region of rat brain.G.Curson and A.R.Green ( 1970$)$

[12]. Rapid method of determination of 5HT 5HIAA in small region of rat brain. Brit journal of pharm 39:623 - 625 . Parent,A.,descarrier, K., Beaudet, A ( 1981 )

[13]. Organization of ascending serotonin systems in the adult rat brain. A radio autographic study after intraventricular of (3H ) 5hydroxytryptamine Neuroscience, 6: 115-138. Fibeger, H.C., miller, J.J., (1977)

[14]. An anatomical and electrophysiological investigation of the serotonergic projection from the dorsal raphe nucleus to the substantia nigra in the rat. Neuroscience $2: 975$-987.

[15]. Kizer JS. Palkovits M, Kopin IJ, Saavedra JM, Brownstein M ( 1976 ) Lack of effect of various endocrine manipulations on tryptophan hydroxylase activity of individual nuclei of the hypothalamus, limbic system and midbrain of the rat. Endocrinology 98 : 743-747

[16]. Fibiger HC, Miller JJ ( 1977 ) AN anatomical and electrophysiological investigation of the serotonergic projection from the dorsal raphe nucleus to the substantia nigra in the rat. Neuroscience $2: 975-987$.

[17]. Coope, J (1996) Hormonal and non-harmonal interventions for menopausal symptoms. Maturi tas , 23: 159-168.

[18]. Crowley, W.R.. O.Donohue., T.L.., Muth, F.A., Jacobious, (1979). Effects of ovarian hormones on levels of luteinizing hormone in plasma and on serotonin concentration of discretic brain nuclei. Brain Rex. Bull 4 : 571-574 Cone. R.G. Davis, C. A.. Goy. R. W .. (1981)

[19]. Effects of ovarian steroids on serotonin metabolism within grossly dissected and micro dissected brain regions of the overiectomized rat. Brain Res Bul $7: 639-644$ 